\title{
Ecohydrology of a seasonal wetland in the Rift Valley: ecological characterisation of Lake Solai
}

\author{
Authors: \\ De Bock, Tanguy \\ Kervyn de Meerendré, Baptiste \\ Hess, Tim \\ Gouder de Beauregard, Anne-Christine
}

\section{Address :}

De Bock, Kervyn, Gouder. Laboratory of Ecology, Gembloux Agricultural University, Passage des Déportés 2, BE 5030 Gembloux, Belgium

Hess: Cranfield University, Silsoe, Bedfordshire, MK45 4DT, United Kingdom.

\section{Emails :}

Tanguy De Bock : tanguydebock@yahoo.co.nz

Baptiste Kervyn : bkdm@hotmail.com

Anne-Christine Gouder : gouder.ac@,skynet.be

Tim Hess : t.hess@,cranfield.ac.uk

\section{Keywords :}

Water use, land use, phytosociology, Kenya, Sporobolus, eco-hydrology

Corresponding author:

Anne-Christine Gouder de Beauregard

Laboratory of Ecology, Gembloux Agricultural University, Passage des Déportés 2, BE 5030 Gembloux, Belgium

\section{Running title:}

Ecohydrology of Lake Solai

Wordcount: 2600 


\section{Abstract -}

The following research describes through an ecohydrological approach, the first assessment of the ecology of Lake Solai, with a particular emphasis on the vegetation. Lake Solai is located $50 \mathrm{~km}$ north of Nakuru in the Rift Valley in Kenya at E36 80'$36^{\circ} 84^{\prime}-\mathrm{N} 00^{\circ} 05^{\prime}-00^{\circ} 08^{\prime}$. It is a shallow lake which follows a very peculiar seasonal water regime, and which faces conflicts between agriculture and conservation water users. In the upper catchment, an overview of the agricultural practices was implemented and river water uses were identified to assess river flows. Crops/grassland and woodland/shrubland were the major land uses, covering about $65 \%$ of the catchment. Closer to the lake, vegetation samples were collected around the lake together with samples of environmental factors such as soil and water quality. Thirteen vegetation communities were identified within four main zonations: forest, grassland, river inlet and rocky outcrop. These communities showed abundance, distribution and diversity determined mostly by the human pressures, the flooding periods and the salinity. Cynodon, Cyperus, and Sporobolus genera were the most abundant. 


\section{Introduction}

Seasonal wetlands are important features in tropical areas. More particularly, from a phytosociological point of view, plant communities in East Africa's wetlands are poorly described (Gouder de Beauregard \& Mahy, 2004; Denny, 1985). The ecohydrology at the catchment level needs to be researched and understood in order to preserve and manage such environments.

The Lake Solai catchment, host to a seasonal wetland reaching $9 \mathrm{~km}^{2}$ in wet periods, is located in the Eastern Rift Valley, Kenya, at E36 $80^{\circ}-36^{\circ} 84^{\prime}-\mathrm{N} 00^{\circ} 05^{\prime}-00^{\circ} 08^{\prime}$. The basin is located in a transitional climatic zone, so that it is described as semi arid to semi humid (FAO, 1978). The rainfall is highly variable within the catchment but averages, according to sources, from 700 to $900 \mathrm{~mm}$ of annual rainfall (Chemilil in Mulama, 1999; Koskei \& Mara, 2000; Koyo \& Ndetei, 2003). The pattern is bimodal with long rains in April and May and short rains in October. The driest season extends from December to March, and the evaporation is estimated at $1800 \mathrm{~mm}$ per year (DailyET 2003 after FAO 2004).

The lake is of great ecological importance, as it offers large habitats for waterfowl and is located between Lake Nakuru and Lake Bogoria in a bird migration highway. It plays also a significant economical role for livestock grazing and watering, and for a small ecotourism industry. 
The objectives of this paper are to present a first assessment of the ecology of the Lake Solai with particular emphasis on the vegetation, by favouring the ecohydrological approach as advocated by Zalewski (2000) and Gouder de Beauregard, Torres \& Malaisse (2002), which integrates the ecological, hydrological and agronomical issues. 


\section{Material and Methods}

The study was carried out after a wet period in August-September 2003 and after an unusually dry period in June 2004.

Land use characteristics of the catchment were assessed from digitised topographic maps (KSS, 1973 and 1974), land cover maps extracted from the AfriCover database (FAO, 2000) and a LANDSAT image (27/01/2000). Ground truthing, which identified the specific land use types, was achieved using a hand-held GPS set (Garmin 76) and ArcGIS software (ESRI) was used to process the information.

River discharges were measured using the velocity-area method or volume timing (Mwakalila, 2003). For each river two variables were estimated: the base flow and the abstraction during the dry season. Base flow was estimated gauging the rivers' flow during the dry season. Water abstractions represented local consumption either for irrigation purposes or household water supplies. These figures were derived from agricultural surveys carried out with local farmers and water users. Lake bathymetry and topography were estimated with a clinometer on land and a meter rule in water along 13 transects.

For plant work, seven transects (T1 to T7) were selected along clear zonations around the lake, starting from dry land to open water, with 4 to 5 sampling points per transect, varying in distance according to vegetation changes (A to E). The minimal area for vegetation sampling was defined at each sampling site via the species-area-curve 
technique (Kent \& Coker, 1995) The species-area curve is normally plotted by using quadrats of successively larger size, until no significant number of new species is encountered, at which point the minimal area is reached, defining a relevé. Abundance at each relevé, or sampling area, was estimated according to the Braun-Blanquet abundance scale (Kent \& Coker, 1995). The Braun-Blanquet coefficients were then rescaled in van der Maarel coefficients and recorded in a raw data matrix (Kent \& Coker, 1995). Plant specimens were collected and identified at the National Botanic Garden of Belgium and the National Herbarium of Kenya.

Environmental parameters of water and soil were determined for each vegetation sampling site, in 2003 and 2004. At each dry sampling point on each transect, the top soil was analysed. $\mathrm{pH}$ was determined with a $\mathrm{pH}$ kit, soil texture was given a scale between sand and clay and soil colour was described using a Munsel chart. For flooded sampling areas, a multimeter (Consort C532T) was used to record $\mathrm{pH}$, electrical conductivity and temperature with a Secchi disk for water transparency. Samples for BOD, total nitrates and phosphorus, total dissolved and suspended solids were collected once for analysis at the KWS Nakuru laboratory. The methods used are listed in the Table 3. 


\section{Results}

\section{Upper catchment}

The Lake Solai catchment covers an area of $175 \mathrm{~km}^{2}$ and is orientated NE-SW, with escarpments clearly delimitating the eastern and western boundaries (Figure 1). Four permanent rivers flow from the eastern escarpment: Maji Tamu and Kasururei originate on the plateau and Kamolo and Chemuka discharge as springs from the hillside (Table 2). There is no surface outflow.

Catchment land use classes (five) are shown in Table 1 and the distribution of the dominant classes are visible in Figure 1. Land use is driven by soil, topographic, hydrologic and anthropogenic variables. Large agricultural fields ( $>0.25$ ha) are located on deep brown and red soils with woodland and shrubland on shallow soils and slopes or following rivers. Land close to the lake is grazed and areas more distant are cropped. Hence, the spatial distribution of land uses follows a centripetal trend where grazing areas favour proximity to the lake's edges and where cropped areas are located in further positions from the centre of the catchment. Woodland and shrubland are either located on remote positions or on prominent landscape features which cannot be exploited for agrarian purposes.

\section{Lower catchment}

Lake Solai lies in a shallow basin (Figure 2) with soils around the lake ranging from silty loam to heavy clay. Brown silty loam soils (FAO cambisols) are in both transitional and deposit-receiving areas. Heavy dark clay soils are distributed around the lakeshores. These are often waterlogged with high salt concentration and can be related 
to the FAO vertisoils and Solonchaks (Driessen et al., 2001). Inflowing river water is near neutral ( $\mathrm{pH} 7.3)$ with low conductivity $(135 \mu \mathrm{S} / \mathrm{cm})$ but rises to $\mathrm{pH} 9.0$ and conductivity of $2398 \mu \mathrm{S} / \mathrm{cm}$ in open water. Secchi transparency is around $12 \mathrm{~cm}$ with highest suspended and dissolved solids concentrations during the dry season (Table 3). Water temperature varies between $20^{\circ} \mathrm{C}$ in the morning to $35^{\circ} \mathrm{C}$ at midday. The various environmental factors determined with their sampling numbers (n) are compiled in Table 3 according to vegetation zones.

\section{Phytosociology}

Fifty-eight plant species in the wet and 36 species in the dry season were recorded. Their abundance-dominance coefficients are presented in Table 4 for the years 2003/2004. Thirteen vegetation communities (C1 to C13) were identified (Figure 2) and eleven of these (excluding rocky areas and a seepage zone) are illustrated in Figure 3. Communities fell into four main zones: dry land, swamp, open water and river inlet.

At the head of the dry land zone, the Acacia xanthophloea Benth. sets the landscape, while the dominant species are at grass level, with the Cynodon dactylon (L.) Pers., Sphaeranthus suaveolens (Forsk.) DC., Cycnium tubulosum (L.F.) Engl. and even the Commelina diffusus Burn. in the wet season only. Within the zone described as swamp, the abundant and wide spread species were Cynodon dactylon, Cyperus laevigatus L., Cyperus dives Del. and the Acacia xanthophloea, the Panicum repens L. and the Sporobolus robustus Kunth. The open water zone contained in dry periods mostly Cyperus dives, Panicum repens, Pistia stratiotes L., Typha domingensis (Pers.) Steud., Sporobolus robustus and in wet periods, significant concentrations of Lemna sp., 
Ludwigia stolonifera (Guill. \& Perr.) Raven and Utricularia spp. Finally, the river inlet was dominated by Cyperus dives, Pistia stratiotes, Ludwigia sp., Polygonum spp.,Commelina sp. and Leersia spp. 


\section{Discussion}

\section{Upper and lower catchment}

The Lake Solai ecosystem relies on (bio)communities which adapt to changing environmental conditions, resulting from the combination of the land and water uses in the catchment, the lack of lake outlet, the precipitation pattern and the high evaporation.

It was shown that up to $50 \%$ of the upper catchment is cultivated; rivers have no buffer zones and water is abstracted, most intensely during dry seasons. The latter reduces and sequences the surface recharge to the lake and leads to flashier responses to rainfall events.

As locals confirm (Von Kaufman, pers. com.) the catchment used to be widely forested before 1975, and the lake was smaller. Kervyn de Meerendré (2004) observed through modelling the catchment's hydrology that the impact of woodland and shrubland on the water balance results in the increase of evapo-transpiration, reduced runoff and deep percolation. The root systems of such covered land are generally deeper than those of short vegetation or agricultural crops. In dry climates woodland can maintain transpiration at high rates for longer, depleting the soil moisture to a greater depth (Mwaura \& Moore, 1991). Hence, the impact of human land use in the catchment through deforestation and intensive farming has changed the hydrology drastically allowing more water to reach the rivers and the lake through runoff.

Closer to the lake, there was obvious pressure from cattle grazing on the vegetation and soil. The chemical water study, on its side, indicated that inflowing river water was 
dilute with relatively low concentrations of suspended material. Concentrations were much higher in lake water where changes in $\mathrm{pH}$ and alkalinity suggest high productivity. Total phosphorus concentrations were exceptionally high, perhaps revealing a geochemical origin. The lack of phosphorus accumulation in the lake compared to the river could indicate that phosphorus is removed in the river inlet by the dense vegetation (Carter, 1955; Viner, 1975). Furthermore, it was observed that the shallow depth of the lake, continuously favouring a mixing of the layers, lead to the light being available for photosynthesis only within the upper surface, making it a potential controlling factor for pelagic primary production.

Finally, in comparison to the $630-1510 \mathrm{mg} / \mathrm{l}$ of Lake Solai, Tarras-Wahlberg, Harper \& Tarras-Wahlberg (2003) record suspended solids values of $760 \mathrm{mg} / 1$ for lake Baringo and $52 \mathrm{mg} / 1$ for what they called a reference undisturbed freshwater lake (Lake Kichiritith) south of Baringo. They highlight how the high values of $\mathrm{pH}$ (8.9), conductivity $(1760 \mu \mathrm{S} / \mathrm{cm})$, alkalinity $(670 \mathrm{mg} / \mathrm{l} \mathrm{CaCO} 3)$, and suspended solids of the Lake Baringo, which relate closely to the Lake Solai, reflect on a high environmental stress originating in irrigation agriculture and excessive grazing in the catchment.

The vegetation communities described around the lake are thus results of seasonality and of drivers originating in the catchment. As the Figure 3 illustrates, three main environmental factors affect the vegetation communities of Lake Solai: flooding regime, salinity and human impacts. The hydrology through its seasonality drives the two first factors but is itself influenced by human practices. The determining factor for those plant communities relates to the flooding regime. Water depths have indeed been 
reported to be one of the most important factors that influence vegetation distribution and species assemblages (Lind \& Visser, 1962) in wetlands. The flooding regime furthermore drives the salinity which appears high as testified by the EC and the salt flowers. Denny (1985) and Howard-Williams (1975) who studied inland wetlands in Africa do also confirm the significant role of flooding and salinity in the abundance, composition and distribution of vegetation.

\section{Phytosociology}

The Lake Solai vegetation shows three main zonations around the lake: the forest, grassland and river inlet. A rocky outcrop on a steep slope in the North West presents a fourth zonation.

The grassland extends along the widest zone. The slope is very small and large monospecific communities can be found. As the slope is little, large salt patches are created through evaporation increasing the soil salinity. It is also a place where cattle are regularly brought in large numbers. This heavy grazing, high salinity and flooding regime leave therefore place only to highly resistant species. Cynodon and Sporobolus genera can grow. In the wet periods, the composition and abundance of the communities booms.

Much of the grassland was originally forest and turned over through human interventions. Acacia sp. used to stand in numbers but faced cutting down for charcoal and field clearance. To the west of the lake where the slope is steeper, some of such forest communities remain. They create a very special habitat for birds and host the 
Aeschynome pfundii, which in the East African herbarium (Agnew \& Agnew, 1994) was only recorded in Lake Solai.

The vegetation communities identified for these two zonations show similarities to the description Howard-Williams (1975) made after a drought period on the Lake Chilwa in Malawi. It highlights how the change in water level creates an environment suitable for few species, such as Aeschynomene spp. and Sporobolus spp., where salinity is prominent.

Besides this, Lake Solai presents a zonation which is by far the most abundant and diverse. The fresh input from rivers flooding the delta and then encountering the brackish water from the lake are host to a dense vegetation of emergents and euhydrophytes.

It appears finally that the changes undergone with the seasons by the vegetation communities are mostly in abundance and composition, such as shown around the river inlet and the lake edges. It is however interesting to notice that the free floating macrophytes Lemna sp. and Utricularia sp. were not to find in the drier period although they were very abundant when the lake was more extended. While BOD and alkalinity undergo the strongest seasonal changes, it can be thought that oxygen demands reaching $600 \mathrm{mg} / \mathrm{l}$, high alkalinity and high EC will not favour growth. There was only one floating plant which seemed to thrive, the Pistia stratiotes. In the literature, P. stratiotes were reported to have a toxic level mostly determined by an EC around $2680 \mu \mathrm{S} / \mathrm{cm}$ (Sooknah \& Wilkie, 2004). Further species which seemed absent or in low abundance in 
the drier period were the Commelina diffusus, a euhydrophyte and Cycnium tubulosum, a grassland emergent.

\section{Conclusion}

The study of a type of wetland rarely researched in Eastern Africa necessitates a catchment wide approach, which is well integrated within the ecohydrology concept.

This paper has presented upper catchment data where land use and rivers were analysed, so that the dynamics of the plant community in the lower catchment could be approached holistically.

The significant human impacts and hydrological changes on the Lake Solai offer a rough environment to survive in, where plants such as Cynodon, Aeschynomene and Sporobolus find their niche and where as much as 13 plant communities co-exist.

The protection of some of these plant communities could benefit the particularly rich birdlife around Lake Solai, this as consequence enabling ecotourism activities based on bird watching to develop. The knowledge and understanding of such environment through the ecohydrological assessment receives thus all its relevance and appears as an appropriate step towards sustainable development. 


\section{Acknowledgements}

Sincere thanks have to be given to the Kenya Wildlife Service, to the staff from the Wetlands Programme and the GIS department. Special thanks to Mr Ndetei and Mr Koyo, Mr Kuloba and Mrs Mutui.

We are also very grateful to the local community from the Solai area, especially to Evans Bowen, Nyeno, Mark Mokotio and John Morogot.

In Nairobi we would like to express our thanks to Mrs Fleur Ngweno, Mr Patrick Picton and Mr Quentin Bourdeaux. In Belgium, very sincere thanks to Mr Malaisse who laid at the origin of the project.

We must express our warm thanks to the reviewer of the article for his very useful comments.

Finally we are very indebted to the "Leopold III Fund for Exploration and Conservation of Nature", to the "Fonds Floribert Jurion" from the Royal Academy of Science and to the Coopération Universitaire au Développement who supported us in the realisation of this study. 


\section{References}

AGNEW, A.D.Q. \& AGNEW, S. (1994) Upland Kenya Wild Flowers. $2^{\text {nd }}$ ed. East Africa Natural History Society, Nairobi.

CARTER, G.S. (1955). The papyrus swamps in Uganda. Heffer, Cambridge.

DAILYET (2003) Dailyet version 2.0. Cranfield University, Silsoe (unpublished).

DENNY, P. (1985) The ecology and management of African wetland vegetation.

Geobotany 6. Dr W. Junk Publishers, Dordrecht.

DRIESSEN, P., DECKERS, J., SPAARGAREN, O. \& NACHTERGAELE, F. (2001)

Lecture notes on the major soils of the world. World Soil Resources Reports 94. FAO, Rome.

FAO (1978) Report on the agro-ecological zones project. Methodology and results for Africa. World Soil Resources Report 48-1. FAO, Rome.

FAO (2004) Land and Water development division. Climwat: a climatic database.

$\leq$ http://www.fao.org/landandwater/aglw/climwat.stm $>$ (August 2004).

GOUDER DE BEAUREGARD, A.-C. \& MAHY, G. (2004) Considering macrophyte species as crucial components of the aquatic ecosystem : a case study of the shallow and freshwater lakes of tropical Eastern Africa. Ecohyrol. Hydrobiol. 4, 337-344.

GOUDER DE BEAUREGARD, A.-C., TORRES, G. \& MALAISSE, F. (2002) Ecohydrology, a new paradigm for bioengineers? Biotechn. Agron. Soc. Env. 6, 17-27. HOWARD-WILLIAMS, C. (1975) Vegetation changes in a shallow African lake: response of the vegetation to a recent dry period. Hydrobiologia 47, 381-398.

KENT, M. \& COKER, P. (1995) Vegetation description and analysis. A practical approach. Wiley, Chichester. 
KERVYN DE MEERENDRÉ, B. (2004) Impact assessment of agricultural practices on water resources in the Lake Solai catchment (Kenya). MSc Thesis. Cranfield University, Silsoe.

KOSKEI, P.K. \& MAARA, N.T. (2000) Community approach to wetland conservation : a case study of Lake Solai, PRA REPORT. KWS Wetland Programme / Egerton University, Nairobi.

KOYO, A. \& NDETEI, R. (2003) Lake Solai Catchment Integrated Management Plan 2003-2008. KWS, Nairobi.

LIND, E.M. \& VISSER, S.A. (1962) A study of a swamp at the north end of Lake Victoria. J. Ecol. 50, 599-613.

MULAMA, M. (1999) Lake Solai Stakeholders Workshop Proceedings. Kenya Wildlife Service/ Netherlands Wetland Programme, Nairobi.

MWAKALILA, S. S. (2003) Estimation of stream flows of ungauged catchments for river basin management. Physics Chem. Earth 28, 935-942.

MWAURA, F. \& MOORE, T. (1991) Forest and Woodland Depletion in the Lake Elementeita Basin, Kenya. Geoforum 22, 17-26.

SOOKNAH, R.D. \& WILKIE, A.C. (2004) Nutrient removal by floating aquatic macrophytes cultured in anaerobically digested flushed dairy manure wastewater. Ecol. Eng. 22, 27-42.

TARRAS-WAHLBERG, H., HARPER, D. \& TARRAS-WAHLBERG, N. (2003) A first limnological description of Lake Kichiritith, Kenya: a possible reference site for the freshwater lakes of the Gregory Rift Valley. South Afr. J. Sci. 99, 494-496. 
VINER, A.B. (1975) Sediments of Lake George (Uganda). II: release of ammonia and phosphate from an undisturbed mud surface. Arch. Hydrobiol. 76, 368-378.

ZALEWSKI, M. (2000) Ecohydrology: the scientific background to use ecosystem properties as management tool toward sustainability of freshwater resources. Ecol. Eng. $16,1-8$. 


\section{Tables}

Table 1- Land use proportions through the Lake Solai catchment

\begin{tabular}{lc}
\hline Land Use & Proportions (\%) \\
\hline Grassland & 8 \\
Woody grassland & 11 \\
Rainfed crops & 14 \\
Woodland and Shrubland & 33 \\
Crops and Grassland & 34 \\
\hline
\end{tabular}

Table 2- Rivers' flows, abstractions and lengths in the Lake Solai catchment

\begin{tabular}{|lccr|}
\hline River & $\begin{array}{l}\text { Discharges in } \mathrm{m}^{3} / \mathrm{s} \\
\text { Base flow }\end{array}$ & \multicolumn{2}{c|}{$\begin{array}{l}\text { River Length } \\
\text { Abstractions } \\
\text { (km) }\end{array}$} \\
\hline Maji Tamu & 0.094 & 0.107 & 10.7 \\
Chemuka & 0.019 & 0.016 & 7.0 \\
Kasururei & 0.017 & 0.015 & 7.4 \\
Kamolo & 0.004 & 0.002 & 5.8 \\
\hline
\end{tabular}

Table 3. Water and soil quality assessment of Lake Solai (mean \pm SD). If different, the number of samples is in brackets. Nutrients (N-NO3, TP), suspended solids, BOD, alkalinity were sampled once on the vegetation transects $\mathrm{T} 5, \mathrm{~T} 2, \mathrm{~T} 2, \mathrm{~T} 4$.

\begin{tabular}{|c|c|c|c|c|c|c|}
\hline & Dry land & Swamp & Open water & Open water & River inlet & Method \\
\hline & 2003 & 2003 & 2003 & 2004 & 2003 & \\
\hline No of samples & 11 & 9 & 13 & 5 & 7 & \\
\hline \multicolumn{7}{|l|}{ Soil } \\
\hline $\mathrm{pH}$ top soil & $6.7 \pm 0.9$ & $8.0 \pm 1.0(6)$ & - & - & - & $\mathrm{pH}$ kit \\
\hline Munsel colour soil & 10YR $3 / 3$ & 10YR 3/1 & - & - & - & Munsel chart \\
\hline Texture & SL-LC & $\mathrm{L}-\mathrm{HC}$ & - & - & - & Texture scale \\
\hline \multicolumn{7}{|l|}{ Water } \\
\hline Water temperature $\left({ }^{\circ} \mathrm{C}\right)$ & & $25.5 \pm 2.7$ & $28.1 \pm 4.0$ & $29.5 \pm 3.3$ & $21.4 \pm 1.3$ & Multimeter (Consort) \\
\hline Secchi transparency $(\mathrm{cm})$ & & $11.8 \pm 12.2(6)$ & $2.4 \pm 0.5(8)$ & $2 \pm 0.0$ & $10.5 \pm 2.2(4)$ & Secchi disk \\
\hline Maximal water depth (cm) & & 60 & 100 & 100 & 60 & Meter \\
\hline $\mathrm{pH}$ water & & $7.9 \pm 0.3$ & $8.1 \pm 0.3$ & $9.0 \pm 0.1$ & $7.3 \pm 0.1$ & Multimeter (Consort) \\
\hline Conductivity $\left(\mu \mathrm{S} \mathrm{cm}^{-1}\right)$ & & $1541 \pm 723$ & $776 \pm 111$ & $2398 \pm 166$ & $135 \pm 13$ & Multimeter (Consort) \\
\hline T. Nitrates (mgN-NO3 $\left.\mathrm{I}^{-1}\right)$ & & $<0.01$ & 0.15 & - & 0.03 & Cadmium reduction \\
\hline T. Phosphorus $\left(\mathrm{mgP} \mathrm{I}^{-1}\right)$ & & 18.70 & 12.20 & 30.70 & 10.40 & Stannous chloride \\
\hline T. Suspended solids $\left(\mathrm{mg} \mathrm{l}^{-1}\right)$ & & 17 & 630 & 1510 & 47 & Photometric \\
\hline $\mathrm{BOD}\left(\mathrm{mg} \mathrm{l}^{-1}\right)$ & & 84 & 101 & 603 & $<5$ & 5 days \\
\hline Alkalinity $\left(\mathrm{mgCaCO} 3 \mathrm{I}^{-1}\right)$ & & 1050 & 300 & 1460 & 60 & Titrimetry \\
\hline
\end{tabular}

Table 4. Phytosociological table with van der Maarel coefficients, for 2003 and 2004 if applicable $(\mathrm{x} / \mathrm{x})$. T represents the transects, and the letter (A to $\mathrm{E}$ ) gives the relevé site. 


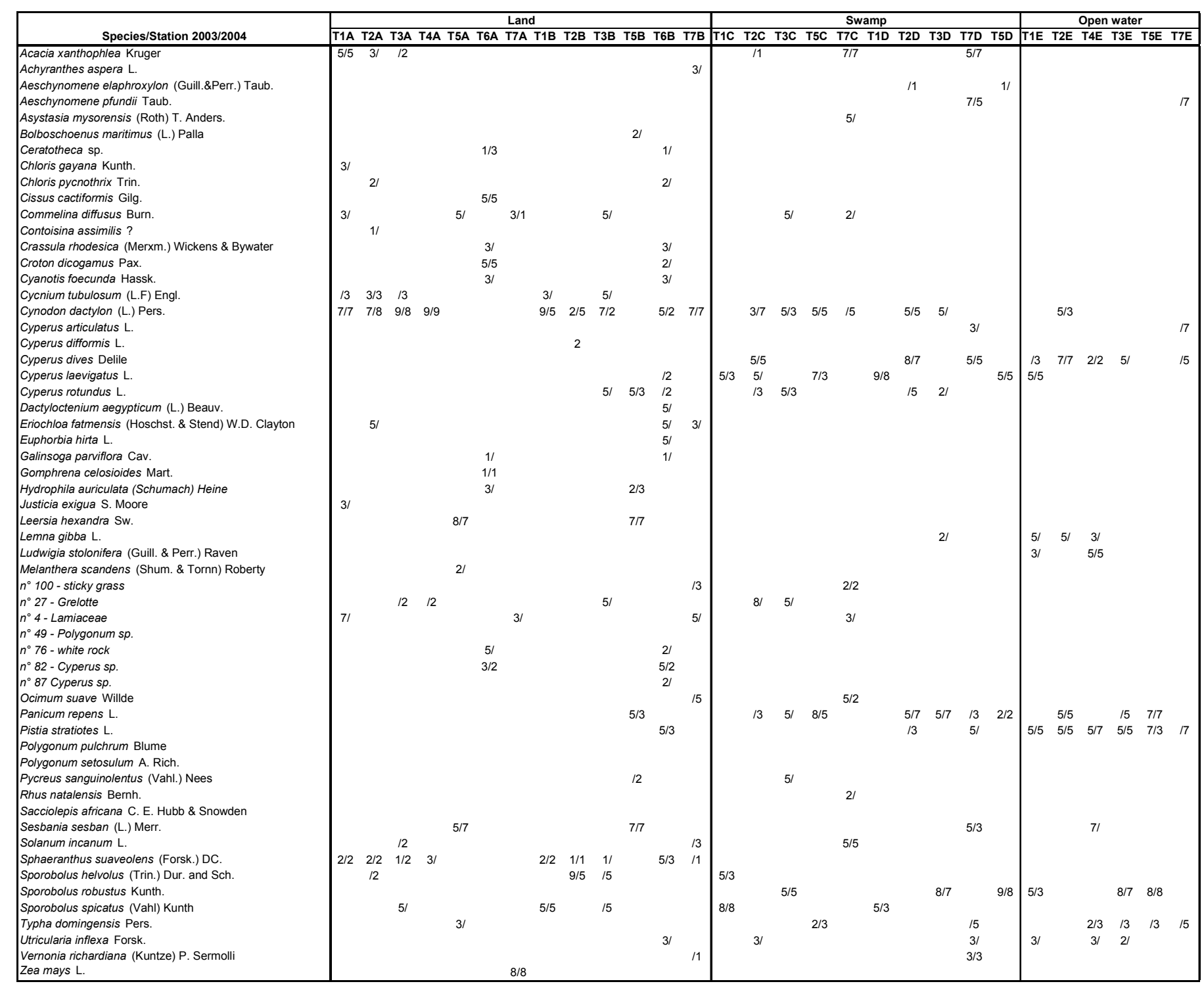




\section{Figure Legends}

Figure 1: Map of a simplified land use of the Lake Solai catchment. The four main rivers are shown: Chem=Chemuka, Kam=Kamolo, Kas=Kasururei, MT=Maji Tamu. Figure 2: Map of the vegetation communities (A1 to A13) and bathymetry of the Lake Solai (2004). T stands for transect.

Figure 3: Diagram of plant communities $(\mathrm{C} 1$ to $\mathrm{C} 11)$ and determining environmental factors. 


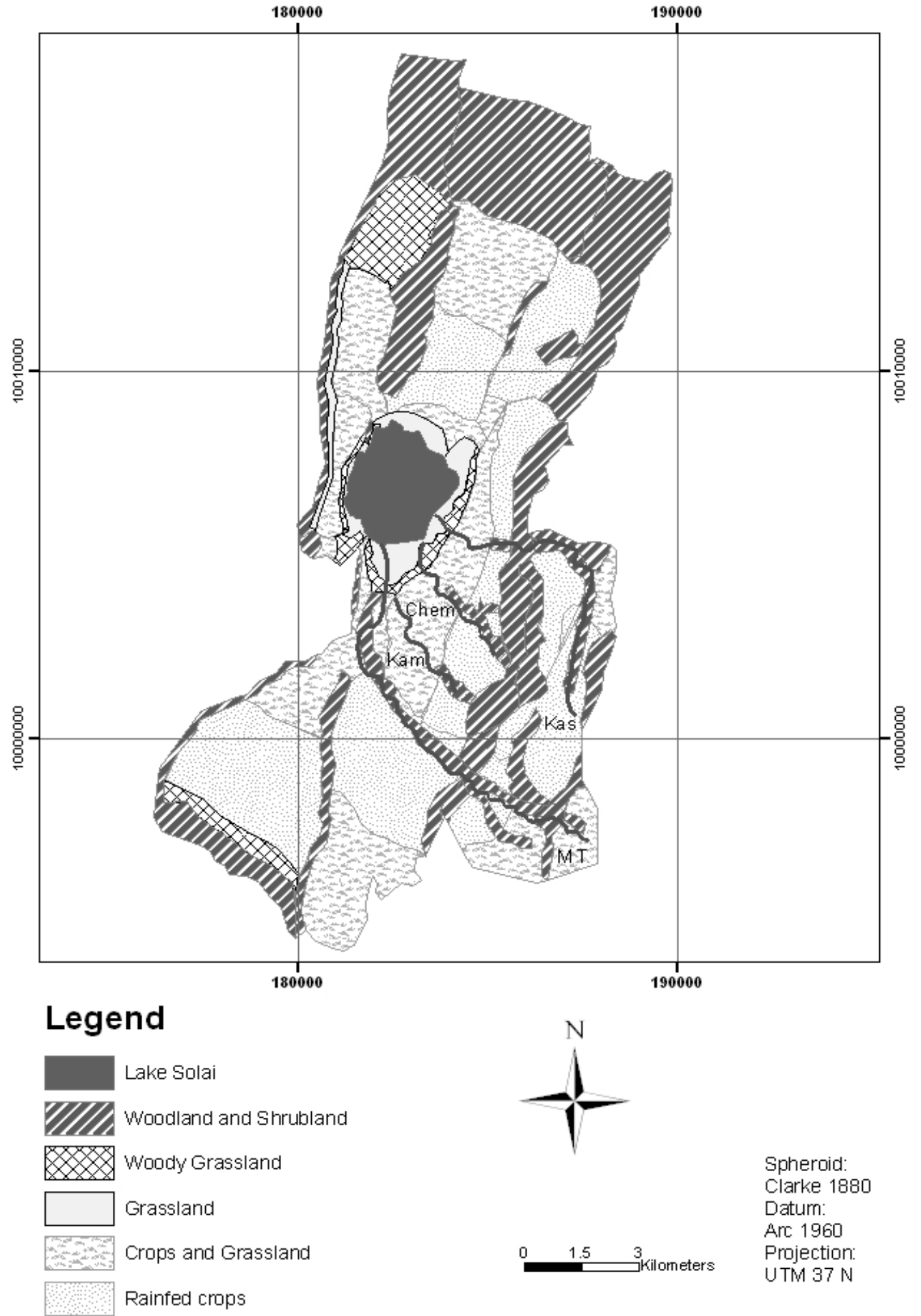




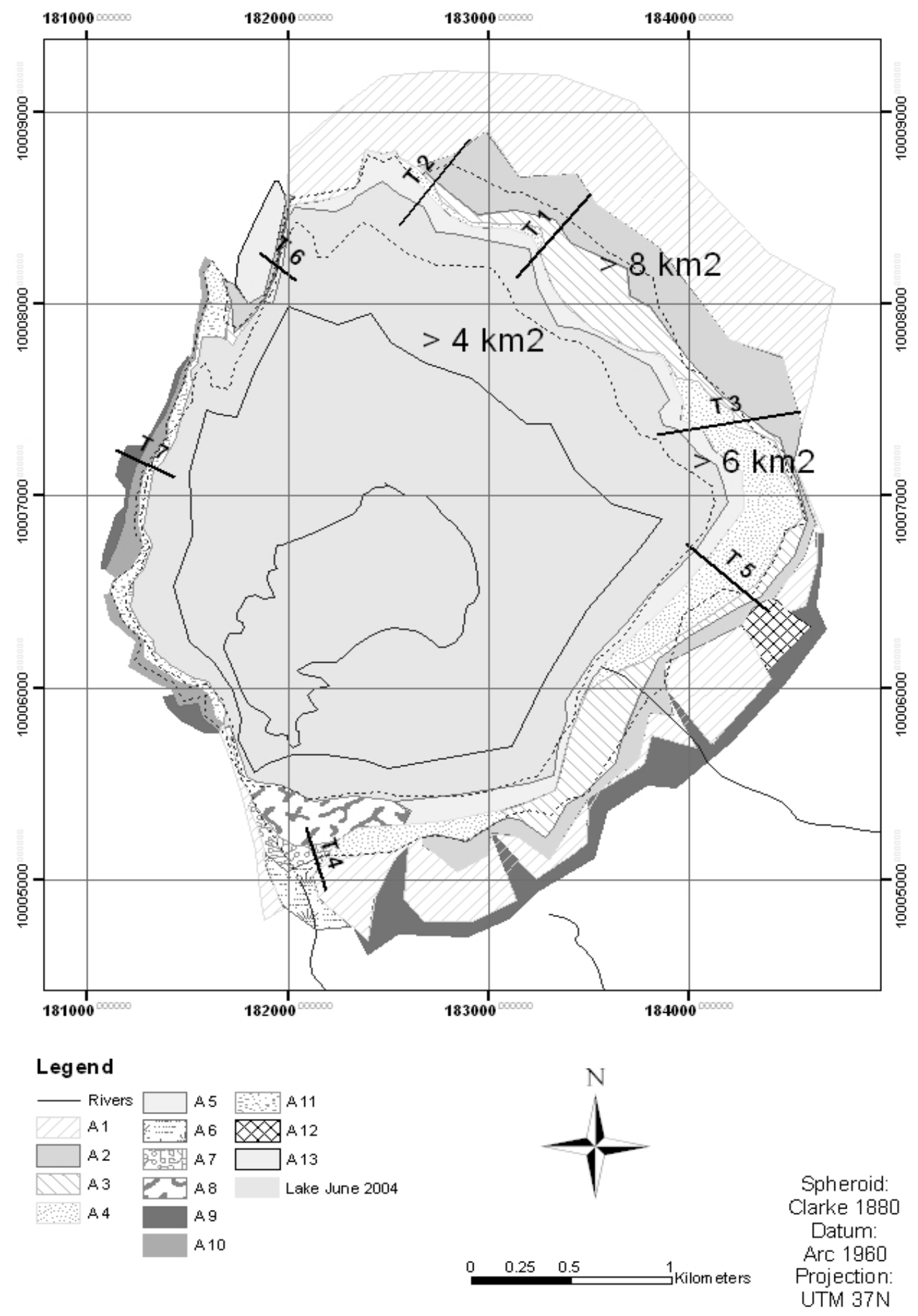




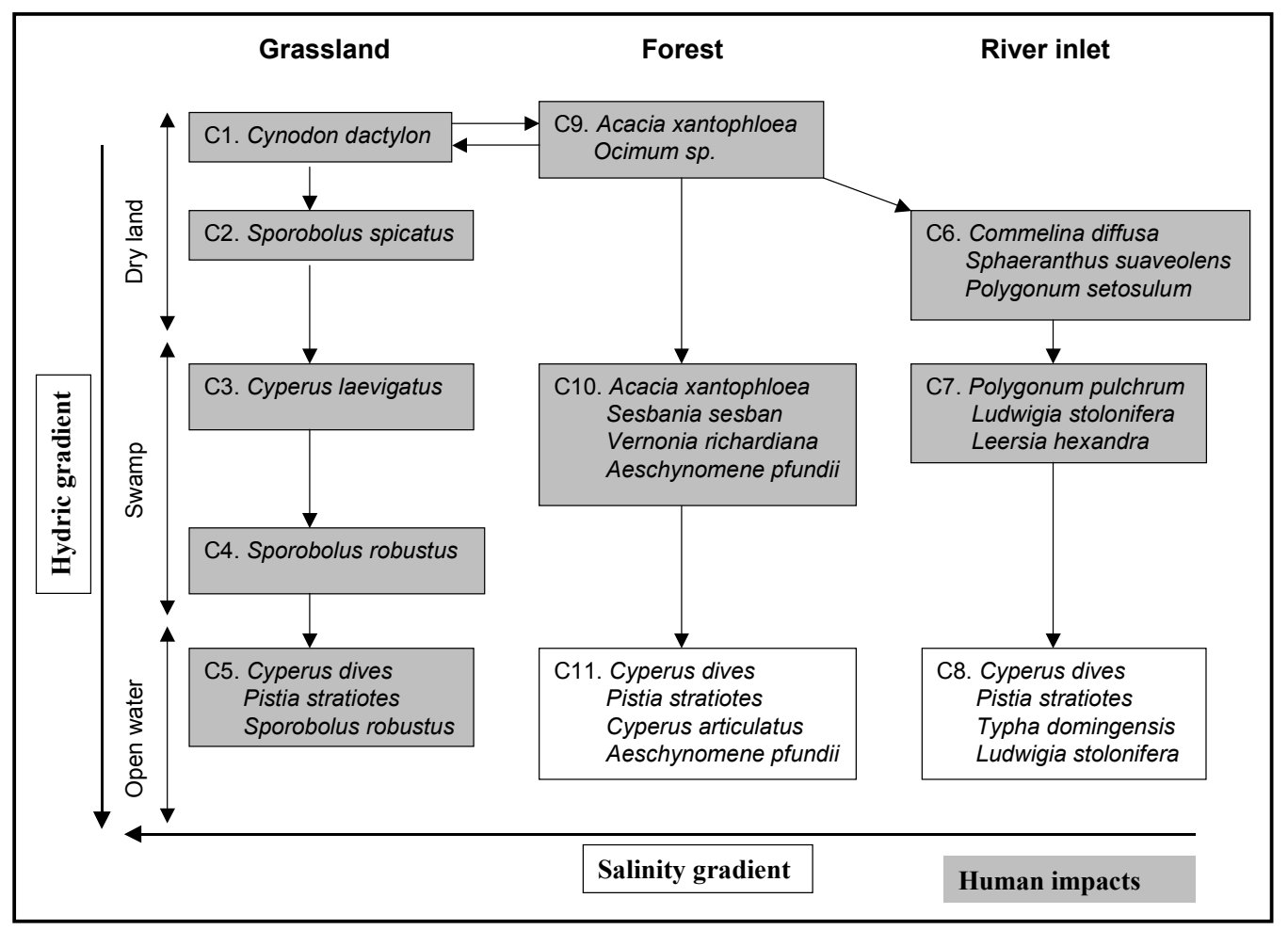

